\title{
化学酸化処理での反応生成物の遺伝毒性に関する研究
}

\author{
小野 芳 朗* \\ 宗 宮 \\ 功* \\ 河 村 正 純*
}

\section{Genotoxicity of By-products in the Chemical Oxidation Processes}

\author{
Yoshiro ONO*, Isao SOMIYA* and Masasumi KAWAMURA* \\ * Dept. of Environmental and Sanitary Eng., Faculty of Engineering, Kyoto University, Yoshida-honmachi, \\ Sakyo-ku, Kyoto 606
}

\begin{abstract}
The umu-test, which can detect the genotoxicity by the induction of error in the repair of damaged DNA, was applied to chemicals which are produced in the chlorination and ozonation processes.

In this research, 37 commercial chemicals were tested by the umu-test. When the retention time of the test strain with chemicals was 2 hours, the genotoxicity of the following organic chemicals were clearly detected with and/or without microsomal activation: $m$ dichlorobenzene ; 1,2,4-trichlorobenzene; bromoform ; dichloroacetic acid; trichloroacetic acid ; chloral ; formaldehyde; ionone; furfurol ; carvone; glyoxal and acrolein. These dose response results are discussed and compared with results obtained in other bacterial assays.

Some of the selected organic compounds - chloroform, bromoform, trichloroethylene, acethyl acetone, acrolein, etc. - were identified as having genotoxicity which increased as the reaction time became longer values. From these results, it can be shown that there are different rate of transportation of chemicals across the cell membrane, the rate of damage and repair of DNA.
\end{abstract}

Key words : umu-test, chemical oxidation, genotoxicity, DNA repair

\section{1. 緒 論}

本研究では水道水，あるいは下水処理水の塩素消毒 やオゾン滅菌操作により副生成物として水中に存在す ると想定される有機物質の安全性を評価する一手法と して, $u m u$ テスト ${ }^{1)}$ の適用による判定を試みた。塩素消 毒においては，とくに生成物中のトリハロメタンを中 心とする有機塩素化合物の変異原性, 発ガン性が指摘 されてきている。一方，塩素消毒に代替する技術とし て普及しつつあるオゾン酸化処理に関しても，その副 生成物の安全性の評価が定量的になされる必要があ る。

ここでは,中村, 小田らによって開発された DNA 修
復にともなう突然変異誘発遺伝子の検出を原理とする umuテストを用いて塩素処理工程, あるいはオゾン処 理工程において生成されると予想されるいくつかの有 機物質に関して，その安全性の評価をなした。

\section{2. 実験方法}

本研究における umuテストでは，凍結保存した試 験菌株を完全培地中で一晚で復活させ，これを TGA 培地で希釈，前培養後，被験化学物質と 2 時間反応さ せた。その後, 菌体の細胞膜を破砕し, SOS 修復反応 で発現した UmuC'- 'lacZ 遺伝子を，それにより産生 した $\beta$-galactosidase 活性で測定している。 また試験対象とする化学物質により試験菌株の

* 京都大学工学部衛生工学科 $\overline{\mathrm{T}} 606-01$ 京都市左京区吉田本町 
SOS 陽性反応を呈するまでの反応時間は異なること が予想される。そこで本研究では開発された常法によ る化学物質との反応時間の 2 時間の他, 長時間試験菌 体と反応させて陽性反応を判定することとした。

生成したDNA修復反応を示す酵素 $\beta$ -galactosidase を抽出する過程において，陰イオン界 面活性剤であるSDS を用いているが,この過程でも一 部のデータはSDS の代わりにトルエン処理を行った。

本研究で扱った被験化学物質は，塩素処理あるいは オゾン処理によって生じると想定されている有機物質

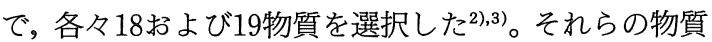
を Table 1 に示す。これらの物質を適当な溶媒(水，工 タノール，DMSO）に溶解し，10倍希釈で約 5 段階の 希釈列を作った。

被験化学物質の中には揮発性を有するものもあるの で，これらについては $50 \mathrm{~m} l$ バイアル瓶に菌懸濁液と 化学物質をいれ, 密栓し, 反応のために振とう培養し た。

陽性の判定は以下に示す方法によった。反応 2 時間 の間に菌の DNA 中での自然発生的に生じる損傷を考 慮し，被験化学物質のある検体量における反応 2 時間 後の酵素活性量 $\mathrm{A}$ から, 溶媒対照における同 2 時間後

Table 1 Chemical source

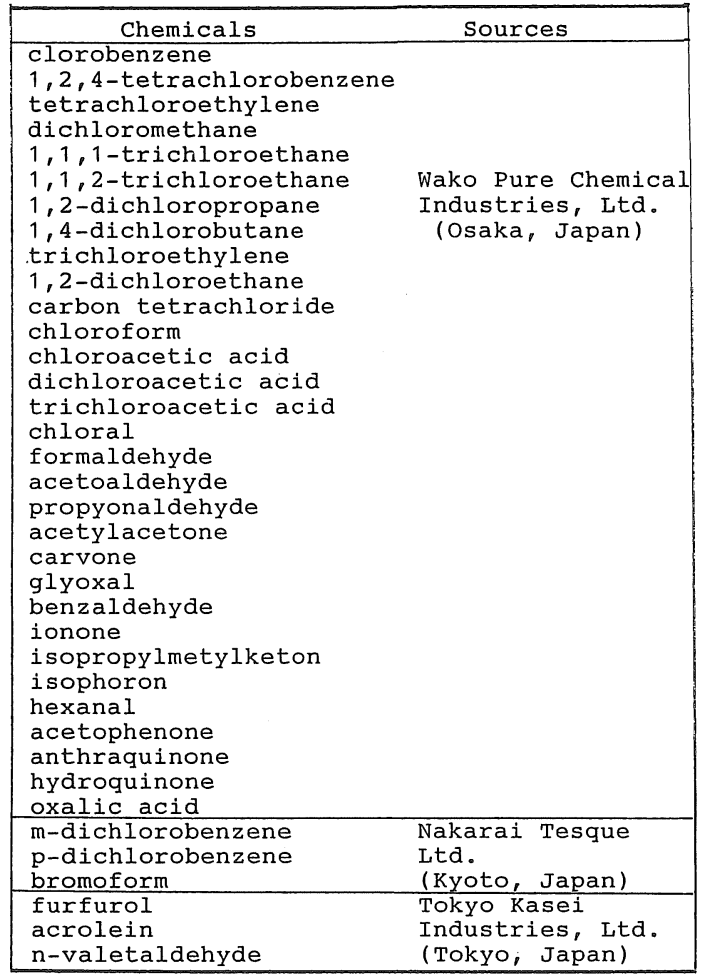

の酵素活性量 B を差し引いた上で, 溶媒対照の酵素活 性量 B で除し，それが 2 以上を強陽性，1 1 から 2 を陽 性，1以下を陰性と判定することとした。

長時間処理の実験は，TGA 培地中で増殖した菌懸 濁液を $100 \mathrm{~m} l$ 培養フラスコに分注し，これに被験化学 物質を所定濃度になるよう投与した。同時に必要に応 じて $\mathrm{S} 9_{\mathrm{mix}}$ 溶液を添加した。培養フラスコを $145 \mathrm{rpm}$, $37^{\circ} \mathrm{C}$ で振とうし， 2 時間毎に $5.4 \mathrm{~m} l$ を採取し，菌体濃 度 $\mathrm{OD}_{600}$ と, $\beta$-galactsidase 活性を測定した。同時に溶 媒対照も測定し，上記と同様の判定基準で被験物質の 遺伝毒性を評価した。

被験物質は, Table 1 の化学物質中, 反応 2 時間の umu テストの結果を勘案して以下のものを選択した。 m-ジクロロベンゼン，1,2,4-トリクロロベンゼ ン，ブロモホルム，クロロホルム，トリクロロエ チレン，テトラクロロエチレン

アセチルアセトン，グリオキサール，イオノン， アクロレイン

\section{3. 結果および考察}

\section{1 反応時間 2 時間に対する判定基準}

被験化学物質の濃度効果の例を Fig.1 (1) (7) に示 した。図は上段が各希釈濃度列に対する菌体濃度を $\mathrm{OD}_{600}$ で，下段は反応 2 時間で呈した $\beta$-galactsidase 活性を示してある。Fig. 1 (1) は典型的な強変異原物質 として知られる $\mathrm{AF}-2$ の dose response を示したもの である。AF-2に対する $u m u$ 遺伝子の誘発，すなわち $\beta$-galactsidase 活性は $0.3 \mu \mathrm{g} \cdot \mathrm{m}^{-1} \cdot \mathrm{OD}_{600}{ }^{-1}(1.0 \mu \mathrm{g} \bullet$ $\left.\mathrm{m} l^{-1}\right)$ で最大に達するが，それ以上の薬品を投与する と，2 時間の反応時間内では DNA 修復ができず, 細胞 は増殖してこないことがわかる。

同様に，Table 1 中に示した被験化学物質に対して 行った結果, $10^{\mathrm{n}}$ の希釈列に対して得られたdose response の例を Fig. 1 (2)〜(7)に示した。いづれも化 学物質と菌懸濁液との反応時間は 2 時間であり, 各物 質である濃度以上になると, $u m u$ 遺伝子の誘発 $(\beta$ -galactsidase 活性の増加) が観察できる。ここで各化 学物質の濃度が比較的高くなると $\mathrm{OD}_{600}$ が減じ, 菌の 生存率が減じているような結果にみられる。一般に Ames 法においては，菌の生存率が50\%以下となるよ うなデータについては, killing の判定をなすことが多 い。ところで本法においては，液体培地中で菌体が化 学物質と反応して 2 時間後に増殖がみられなかったこ とは，必ずしも菌が死に至ったとは断じ得ず，いわゆ る静菌作用によって増殖が阻害され，2 時間の反応時 間内では増殖してこなかったことを表していると考え られる。このことが化学物質による溶菌作用ならば, 

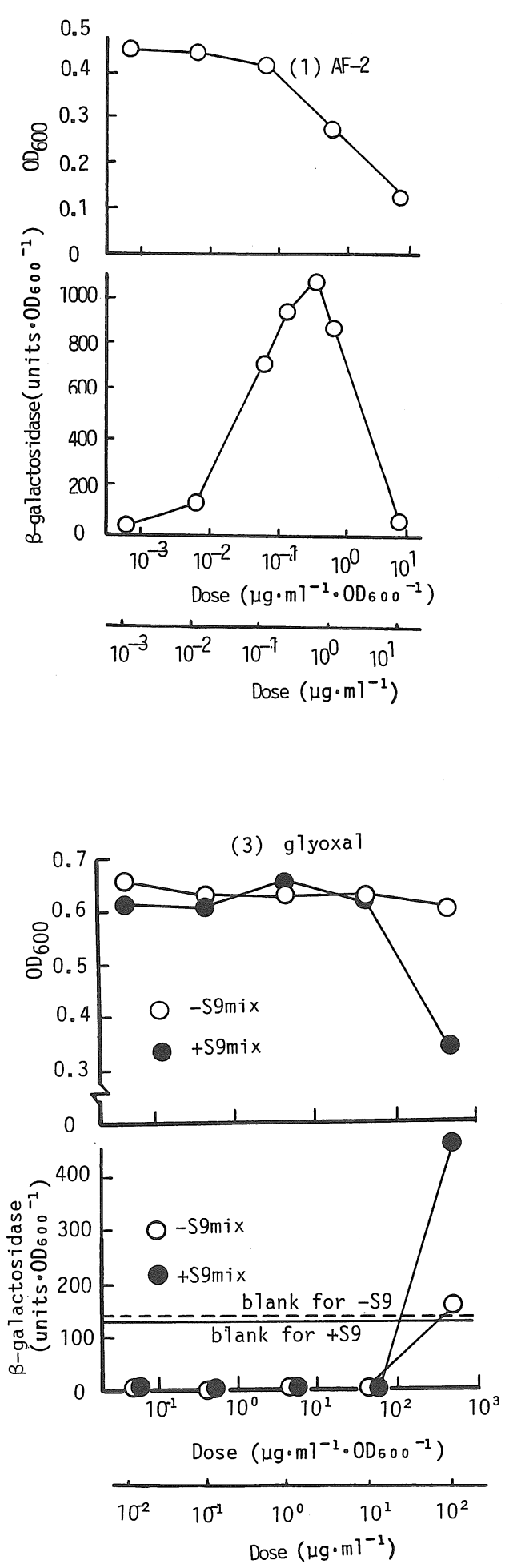
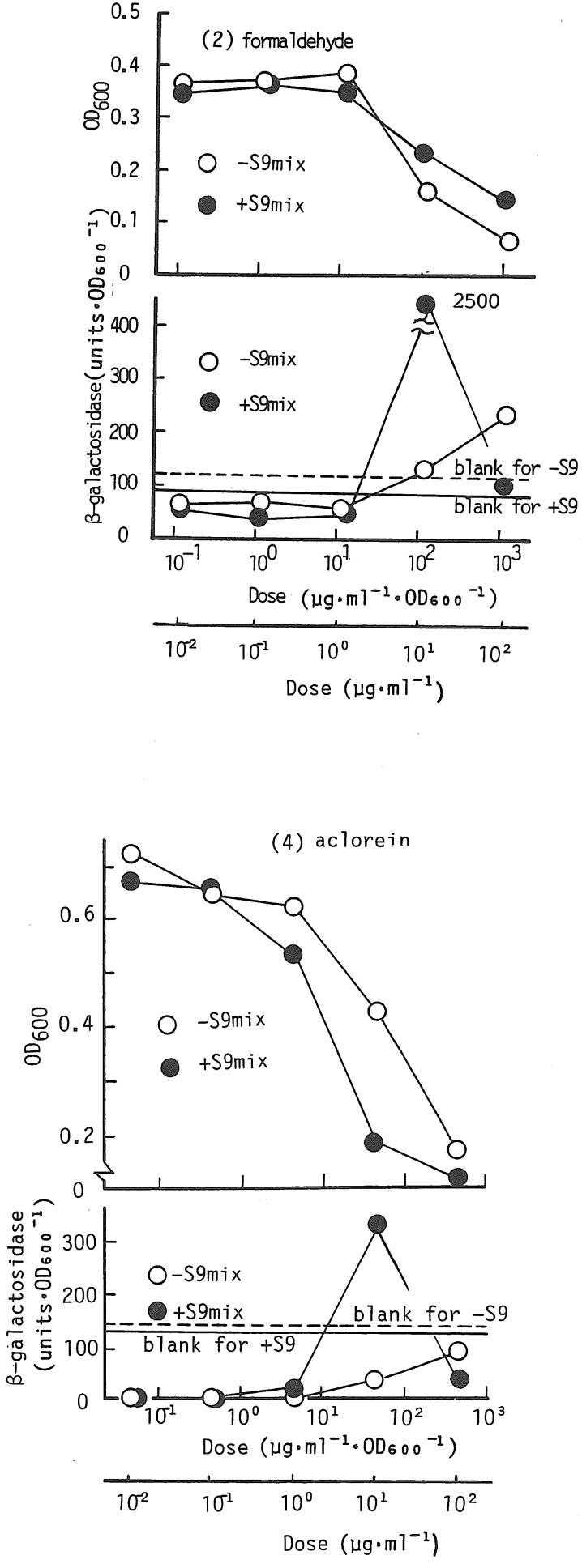

Fig. 1 Dose-related response of tested chemicals 

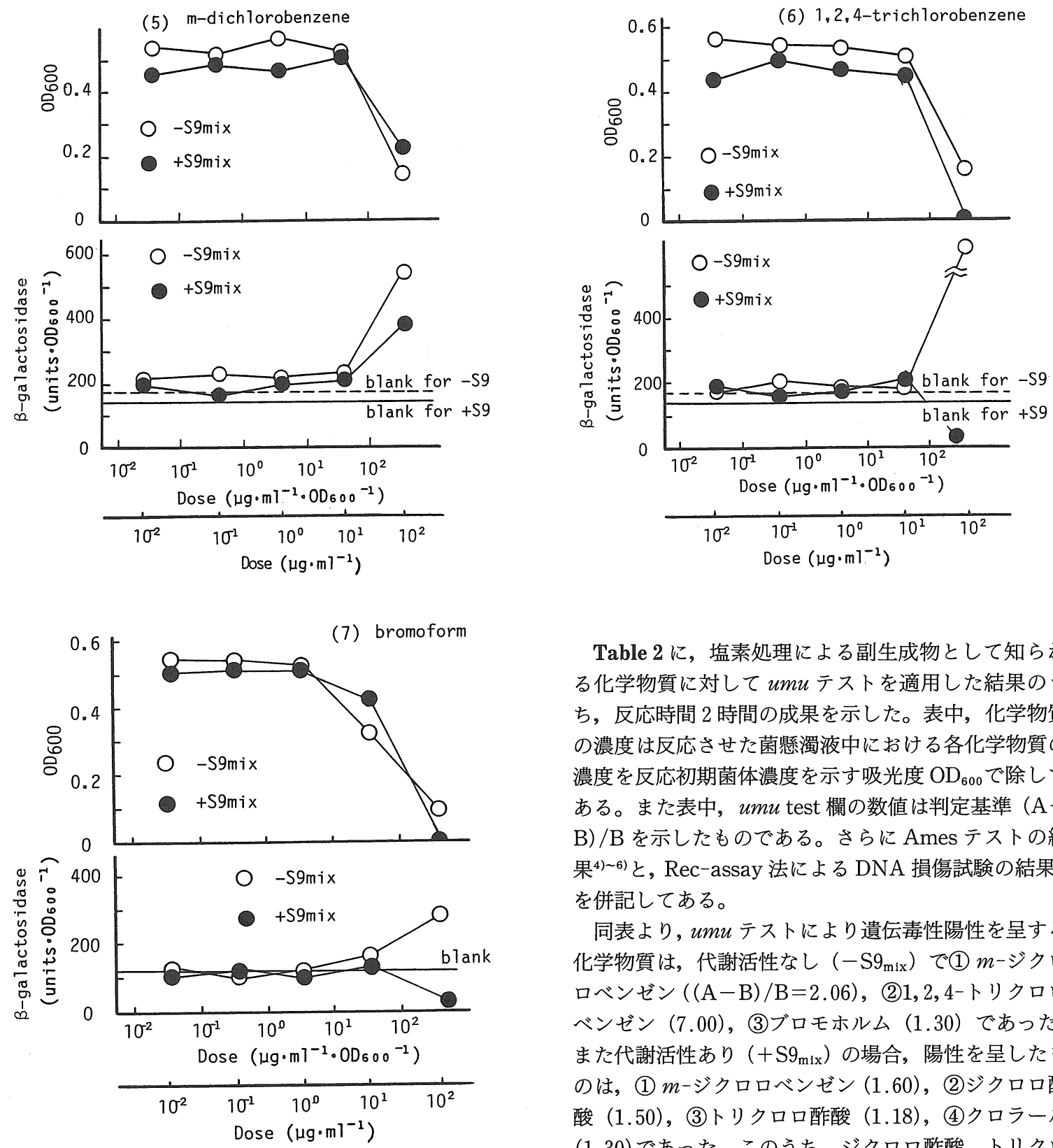

Table 2 に，塩素処理による副生成物として知られ る化学物質に対して $u m u$ テストを適用した結果のう ち，反応時間 2 時間の成果を示した。表中，化学物質 の濃度は反応させた菌懸濁液中における各化学物質の 濃度を反応初期菌体濃度を示す吸光度 $\mathrm{OD}_{600}$ で除して ある。また表中， $u m u$ test 欄の数値は判定基準 $(\mathrm{A}-$ B) /B を示したものである。さらに Ames テストの結 果4) 6) と, Rec-assay 法による DNA 損傷試験の結果7) を併記してある。

同表より,umuテストにより遺伝毒性陽性を呈する 化学物質は，代謝活性なし $\left(-\mathrm{S} 9_{\mathrm{m} \mid \mathrm{x}}\right)$ で(1) $m$-ジクロ ロベンゼン ((A-B)/B=2.06)，(2)1，2，4-トリクロロ ベンゼン (7.00), (3)ブロモホルム（1.30）であった。 また代謝活性あり（+S $\left.9_{\mathrm{mix}}\right)$ の場合, 陽性を呈したも のは，(1) $m$-ジクロロベンゼン (1.60)，(2)ジクロロ酢 酸 (1.50)，(3)トリクロロ酢酸 (1.18), (4)クロラール (1.30)であった。このうち，ジクロロ酢酸，トリクロ 口酢酸は比較的低い濃度 $\left(58.5 \mu \mathrm{g} \cdot \mathrm{m}^{-1} \cdot \mathrm{OD}_{600}{ }^{-1}(10\right.$ $\left.\left.\mu \mathrm{g} \cdot \mathrm{m} l^{-1}\right)\right)$ で陽性を示した。また, $+\mathrm{S} 9_{\text {mix }}$ で1, 2, 4-卜 リクロロベンゼンとブロモホルムは，表示した濃度に

再び増殖することはあり得ないが，DNA の損傷によ る増殖阻害ならば, 修復機構は働いていると考えられ， umuDC 遺伝子の誘発は，この間も続いていると考え られる。その意味で units $/ \mathrm{OD}_{600}$ は $u m u D C$ 遺伝子の 誘発と，細胞増殖双方を示す単位といえる。細胞死と 判定できるケースは Fig. 1 (6) (7)の+S $9_{\text {mix }}$ のよう に, $\mathrm{OD}_{600} も \beta$-galactsidase 活性も減じた場合と考え られる。 おいては，反応 2 時間内にて菌体の増加および $\beta$ -galactsidase 活性の増加も観察できず, 前記のような 化学的ストレスとは異なり，いわゆる細胞死 (killing) と判定してある。

以下の物質は $\mathrm{S} 9_{\mathrm{mix}}$ の投与により本試験において $(\mathrm{A}-\mathrm{B}) / \mathrm{B}$ 值を増した。

クロロベンゼン； $p$-ジクロロベンゼン；ジクロロ 
Table 2 Evaluation of genotoxicity for chlorination by - products in 2 hours reaction

\begin{tabular}{|c|c|c|c|c|c|c|c|c|c|}
\hline \multirow{2}{*}{$\begin{array}{l}\text { Chemicals } \\
\text { chlorobenzene }\end{array}$} & \multicolumn{2}{|c|}{$\begin{array}{l}\text { Concentration } \\
\left(\mu \mathrm{g} \cdot \mathrm{m}^{-1} \cdot 0_{600}^{-1}\right)(\mu \mathrm{g} \cdot \mathrm{m}\end{array}$} & \multicolumn{4}{|c|}{ umu test $(A-B) / B$} & $\begin{array}{ll}\text { Ames } & R \\
\text { test } & S\end{array}$ & \multicolumn{2}{|c|}{$\begin{array}{l}\text { Rec-as. } \\
\text { S9- S9+ }\end{array}$} \\
\hline & 442.5 & 100 & 0.45 & - & 0.67 & - & - & & \\
\hline m-dichlorobenzene & 442.5 & 100 & 2.06 & ++ & 1.60 & + & - & & \\
\hline p-dichiorobenzene & 442.5 & 100 & 0.02 & - & 0.16 & - & $-(z)$ & & \\
\hline $1,2,4$-trichlorobenzene & 442.5 & 100 & 7.00 & t+ & - & $\mathrm{k}$ & - & - & $+t$ \\
\hline tetrachloroethylene & 442.5 & 100 & 0.10 & - & 0.13 & - & + & & + \\
\hline dichloromethane & 442.5 & 100 & 0 & - & 0.48 & - & + & & \\
\hline $1,1,1$-trichloroethane & 476.2 & 100 & 0.76 & - & 0.21 & - & + & & \\
\hline $1,1,2$-trichloroethane & 476.2 & 100 & 0.08 & - & 0 & - & - & & \\
\hline 1,2-dichloropropane & 476.2 & 100 & 0 & - & 0.07 & - & + & & \\
\hline 1,4-dichlorobutane & 476.2 & 100 & 0 & - & 0 & - & ? & & \\
\hline bromoform & 476.2 & 100 & 1.30 & + & - & $\mathrm{k}$ & + & & ++ \\
\hline trichloroethylene & 476.2 & 100 & 0.36 & - & 0.06 & - & + & - & - \\
\hline 1,2-dichloroethane & 393.7 & 100 & 0 & - & 0.18 & - & + & & \\
\hline carbon tetrachloride & 393.7 & 100 & 0.46 & - & 0.30 & - & $+(M)+$ & ++ & $r$ \\
\hline chloroform & 393.7 & 100 & 0.22 & - & 0 & - & + & - & ++ \\
\hline chloroacetic acid & 485.4 & 100 & 0.08 & - & 0.34 & - & - & & \\
\hline dichloroacetic acid & 58.5 & 10 & 0.47 & - & 1.50 & + & - & & \\
\hline trichloroacetic acid & 58.5 & 10 & 0.72 & - & 1.18 & + & + & & \\
\hline chloral & 58.5 & 10 & 0.81 & - & 1.30 & + & + & & \\
\hline
\end{tabular}

Concentration indicates the minimum concentration which is defined to be positive. S9-; Without microsomal activation

S9+;With microzomal activation

$\mathrm{k}$; bacterial cells were killed

$r$;reverse effect in Rec-assay

++ istrongly positive

+ ipositive

-inegative

Data of Ames test ( $\mathrm{Z})$; Zeiger

(M) ; MacCann et al.

others;RTECS

Data of Rec-assay;Matsui et al.

メタン；1,2-ジクロロエタン；クロロ酢酸；ジクロ

ロ酢酸；トリクロロ酢酸；クロラール

また，1，2,4-トリクロロベンゼンとブロモホルムは $\mathrm{S} 9_{\mathrm{mix}}$ の投与によって毒性が増し,この反応 2 時間内で の細胞死が観察された。

さらに umu テストの結果を Ames 法ならびに Rec -assay の結果と比較した。umu テストで 2 時間の反 応で陰性と判定された物質のうち，テトラクロロエチ レン，ジクロロメタン，1,1,1-トリクロロエタン，1， 2-ジクロロプロパン，トリクロロエチレン，1，2-ジク ロロエタン,クロロホルムは, Ames 法では陽性と判定 されている。このことは, Ames 法は化学物質を投与 し，mutationをおこして増殖コロニーを検出するま で，判定に48時間要しているのに対し，umuテストで は 2 時間での結果をみていることから，反応時間の差 に起因している可能性が考えられる。したがって，こ こで試験した19種の有機塩素化合物に対しては, 反応 時間を長くとることにより，陽性反応を示す物質も存 在することが予想される。一方の Rec-assay と umu テストの関係は，Rec-assay が recA 遺伝子の有無に よるDNA 損傷試験であるのに対し， DNA 損傷時の最初の誘発が $r e c A$ 遺伝子の発現，およ び続いて起こる $u m u D C$ 遺伝子と $l a c Z$ により直接測
定している。これら反応機構の点から，両法の関連は 大きいように思われるが，試験菌の増殖までを考える と,両方の結果を連続した SOS 反応の原理の中で捉え きれないことも事実であることが観察された。表中で の有機塩素化合物では Rec-assay で陽性と判定され, umu テストで陰性であった物質にはテトラクロロエ チレン, 四塩化炭素, クロロホルムがあるが, recA の 発現により，その後細胞が死んだのか，あるいは変異 したのかは DNA 損傷試験ではわからず，少なくとも 2 時間内では $u m u D C$ 遺伝子の発現はみられなかっ たということになる。

Table 3 には同様にオゾン処理について生成される とされる化学物質について, umu テストの結果を示し た。

- $\mathrm{S} 9_{\text {mix }}$ で陽性を示したものは, (1)ホルムアルデヒド (( $\mathrm{A}-\mathrm{B}) / \mathrm{B}=1.46)$ ，(2)イオノン (5.37) であった。ま た $+\mathrm{S} 9_{\mathrm{m} 1 \mathrm{x}}$ で反応した化学物質は, (1)ホルムアルデヒド (38.8), (2)フルフラール (1.02), (3)カルボン (2.21), (4)グリオキサール (2.50)，(5)アクロレイン (1.80) で あった。このうち比較的低濃度で陽性を呈した物質は ホルムアルデヒド $\left(123.5 \mu \mathrm{g} \cdot \mathrm{m}^{-1} \cdot \mathrm{OD}_{600}{ }^{-1}(10 \mu \mathrm{g}\right.$ ・ $\left.\left.\mathrm{m} l^{-1}\right)\right)$ とアクロレイン $\left(49.3 \mu \mathrm{g} \cdot \mathrm{m} l^{-1} \cdot \mathrm{OD}_{600}{ }^{-1}(10 \mu \mathrm{g} \cdot\right.$ $\left.\left.\mathrm{m} l^{-1}\right)\right)$ である。 
Table 3 Evaluation of genotoxicity for ozonation by-products in 2 hours reaction

\begin{tabular}{|c|c|c|c|c|c|c|c|c|c|}
\hline \multirow{2}{*}{$\begin{array}{l}\text { Chemicals } \\
\text { formaldehyde }\end{array}$} & \multicolumn{2}{|c|}{$\begin{array}{l}\text { Concentration } \\
\left(\mu \mathrm{g} \cdot \mathrm{m}^{-1} \cdot 0 D_{600^{-1}}\right)\left(\mu \mathrm{g} \cdot \mathrm{m} \mathrm{l}^{-}\right.\end{array}$} & ${ }_{\text {2) }}^{u m u}$ & \multicolumn{3}{|c|}{ test $(A-B) / B$} & $\begin{array}{l}\text { Ames } \\
\text { test }\end{array}$ & \multicolumn{2}{|c|}{$\begin{array}{l}\text { Rec-as. } \\
\text { S9-S9+ }\end{array}$} \\
\hline & 123.5 & 10 & 1.46 & + & 38.8 & ++ & + & ++ & ++ \\
\hline acetaldehyde & 1234.6 & 100 & 0.25 & - & 0.95 & - & + & - & + \\
\hline propionaldehyde & 1234.6 & 100 & 0.25 & - & 0.93 & - & - & - & $\mathrm{r}$ \\
\hline furfural & 1234.6 & 100 & 0.22 & - & 1.02 & + & + & $\mathrm{r}$ & - \\
\hline acetylacetone & 1234.6 & 100 & 0.57 & - & 0.95 & - & - & - & + \\
\hline carvone & 1234.6 & 100 & 0.29 & - & 2.21 & ++ & - & - & - \\
\hline glyoxal & 492.6 & 100 & 0.98 & - & 2.50 & ++ & + & ++ & ++ \\
\hline acrolein & 49.3 & 10 & 0.17 & - & 1.80 & + & + & ++ & - \\
\hline benzaldehyde & 492.6 & 100 & 0.11 & - & 0.27 & - & + & - & + \\
\hline ionone & 492.6 & 100 & 5.73 & $+t$ & - & $\mathrm{k}$ & - & $r$ & $r$ \\
\hline n-valeraldehyde & 492.6 & 100 & 0.28 & - & 0.51 & - & - & - & - \\
\hline isopropylmethylketon & 492.6 & 100 & 0.13 & - & 0.25 & - & - & & \\
\hline isophoron & 680.3 & 100 & 0.55 & - & 0.46 & - & - & + & $r$ \\
\hline hexanal & 680.3 & 100 & 0.46 & - & 0.65 & - & - & & \\
\hline acetophenone & 680.3 & 100 & 0.22 & - & 0.33 & - & - & & \\
\hline anthraquinone & 680.3 & 100 & 0 & - & 0.04 & - & + & & \\
\hline hydroquinone & 680.3 & 100 & 0 & - & 0.07 & - & + & & \\
\hline oxalic acid & 719.4 & 100 & 0.01 & - & 0.14 & - & - & & \\
\hline
\end{tabular}

Concentration indicates the minimum concentration which is defined to be positive.
s9-;Without microsomal activation
s9+; With microsomal activation
k; bacterial cells were killed
rireverse effect in Rec-assay
++ istrongly positive
+ ipositive
- inegative
Data of Ames test;RTECS
Data of Rec-assay;Matsui et al.

$\mathrm{S} 9_{\mathrm{mix}}$ の投与でおおむねの物質は $(\mathrm{A}-\mathrm{B}) / \mathrm{B}$ 值を増 加させている。またイオノンは $\mathrm{S} 9_{\mathrm{mix}}$ の投与で反応時 間 2 時間では細胞死と判定した。

以上の結果を Ames テスト や Rec-assay 法7)と比 較してみると，18種のカルボニル化合物に関しては， ほぼ一致した判定結果を示しているといえる。

これらの事実より，物質群により各アッセイの原理 上判定結果の一致に差異を生じることが示唆され， $u m u$ テストにおいては次節に示すように反応時間に ついて検討を試みることとする。

\section{2. 反応時間を長時間とした場合の判定結果}

細胞の化学物質による増殖阻害では，化学物質の夕 ンパク質などの細胞成分との反応, DNA との結合, 細 胞膜との反応等が原因とされ，細胞が増殖を抑制され る静菌作用が観察されることがある ${ }^{8)}$ 。また化学物質 の構造や，物理化学的性状が生物への毒性に関連する ことは，たとえば化学物質の疎水性が分子の生体膜透 過性評価上の主要なパラメータとなることなどが指摘 されている9 。このように開発された常法による被験 化学物質との反応時間は 2 時間とされているものの， 物質によっては, 細胞膜の透過や, 細胞質内拡散, DNA 塩基との反応に時間を要するものも存在することを想 定される。実際，本法の開発者である小田らも hydro- gen peroxide や glutaraldehyde などの物質について は反応 5 時間の中で $u m u D C$ 遺伝子の誘発を検討し ている ${ }^{10)}$ 。そこで前項で示した Table 2 および Table 3 の結果から，短時間処理ばかりでなく，試験菌株と化 学物質を $2 \sim 24$ 時間反応させ，菌の $\beta$-galactsidase (umuDC 遺伝子) の誘導を観察した。結果を Table 4 に示した。

表中には被験物質を試験菌懸濁液に与えたときの濃 度 $\mu \mathrm{g} \cdot \mathrm{m} l^{-1} \cdot \mathrm{OD}_{600}^{-1}\left(()\right.$ 中は $\left.\mu \mathrm{g} \cdot \mathrm{m} l^{-1}\right)$ に対しての， 代謝活性なし $\left(-\mathrm{S} 9_{\mathrm{mix}}\right)$ と代謝活性あり（+S $9_{\mathrm{mix}}$ ) の 結果を記した。反応の陽性, 陰性の表示 $(++,+,-)$ は，被験物質を菌濁液に投与した直後からの反応時間 2 ２4時間に対して示されており，各々溶媒ブランク の值に対して，前述と同じで判定方法によった。また 同様に Ames テストと Rec-assay 法の結果を併記し た。

本表より，これら化学物質と試験菌株との反応時間 を常法の 2 時間に比して，より長くとることで，陽性 反応を強く呈したものがあることがわかる。

たとえば，m-ジクロロベンゼンは+ $\mathrm{S} 9_{\text {mix }}$ で，濃度 $370 \mu \mathrm{g} \cdot \mathrm{m} l^{-1} \cdot \mathrm{OD}_{600}{ }^{-1}\left(10 \mu \mathrm{g} \cdot \mathrm{m} l^{-1}\right)$ の場合， $2 \sim 6$ 時 間でも陽性を示していたが，反応開始後20時間におい て，強陽性を呈するようになった。 
またー $\mathrm{S} 9_{\mathrm{mix}}$ でのブロモホルムも2 時間で陽性を示 したが，よりその陽性反応を強く呈するようになっ た。 $+\mathrm{S} 9_{\text {mix }}$ においては 2 時間では陰性と判定されてい たが，4 時間以後，強い陽性を示すようになった。さ らにクロロホルムは比較的高い濃度 $\left(1000 \mu \mathrm{g} \cdot \mathrm{m} l^{-1}\right)$ に おいて反応時間を長くとることにより, $+-\mathrm{S} 9_{\text {mix }}$ の双 方において陽性を呈するようになった。トリクロロエ チレン，テトラクロロエチレンもーS $9_{\operatorname{mix}}$ において，反 応20時間後に陽性反応を示した。

このように本研究で扱った有機塩素化合物は,
Table 2 における反応 2 時間での判定では, Ames 法に おいて陽性を示したデー夕に対し, umuテストでは陰 性と判定されたものが比較的多かったが，反応時間を 長くとることにより陽性反応を呈するものがあること がわかった。

一方，Rec-assay の結果と比較してみると，Rec -assay で陰性と判定された物質は, $-\mathrm{S} 9_{\text {mix }}$ での1,2, 4-トリクロロベンゼン, ブロモホルム，クロロホルム， トリクロロエチレン，テトラクロロエチレンであった が，umuテストでは陽性を示し得た。逆に Rec-assay

Table 4 Evaluation of genotoxicity for by-products in long-term reaction

\begin{tabular}{|c|c|c|c|c|c|c|c|c|c|}
\hline Chemicals & $\begin{array}{c}\text { concentration } \\
\mu \mathrm{g} \cdot \mathrm{ml}^{-1} \cdot \mathrm{OD}_{-1} \rho^{0} \\
\left(\mu \mathrm{g} \cdot \mathrm{ml}^{\mathrm{m}}\right)^{0}\end{array}$ & S9- r & $\begin{array}{c}\text { reaction } \\
\text { time } \\
\text { (hrs.) }\end{array}$ & $\begin{array}{c}\text { concentration } \\
\mu \mathrm{g} \cdot \mathrm{ml}^{-1} \cdot \mathrm{OD}=1 \\
\left(\mu \mathrm{g} \cdot \mathrm{ml}^{-1} \mathrm{~g} 00\right.\end{array}$ & $\mathrm{S9+}$ & $\begin{array}{l}\text { reaction } \\
\text { time } \\
\text { (hrs.) }\end{array}$ & Ames & \multicolumn{2}{|c|}{$\begin{array}{c}\text { Rec } \\
S 9-S 9+\end{array}$} \\
\hline $\begin{array}{c}\text { m-dichloro } \\
\text { benzene }\end{array}$ & $\begin{array}{c}196 \\
(100)\end{array}$ & $\begin{array}{l}+t \\
++ \\
t+\end{array}$ & $\begin{array}{l}2 \\
4 \\
6\end{array}$ & $\begin{array}{l}370 \\
(100)\end{array}$ & $\begin{array}{r}+ \\
+ \\
+ \\
++\end{array}$ & $\begin{array}{r}2 \\
4 \\
6 \\
20\end{array}$ & - & $?$ & \\
\hline $\begin{array}{c}1,2,4-\text { trichloro } \\
\text { benzene }\end{array}$ & $\begin{array}{l}185 \\
(100)\end{array}$ & $\begin{array}{r}+ \\
++ \\
++ \\
++\end{array}$ & $\begin{array}{r}2 \\
4 \\
6 \\
20\end{array}$ & $\begin{array}{l}370 \\
(100)\end{array}$ & $\begin{array}{l}- \\
- \\
- \\
-\end{array}$ & $\begin{array}{r}2 \\
4 \\
6 \\
20\end{array}$ & - & - & ++ \\
\hline bromoform & $\begin{array}{c}185 \\
(100)\end{array}$ & $\begin{array}{r}+ \\
+ \\
++ \\
++\end{array}$ & $\begin{array}{r}2 \\
4 \\
6 \\
20\end{array}$ & $\begin{array}{c}370 \\
(100)\end{array}$ & $\begin{array}{l}- \\
++ \\
++ \\
++\end{array}$ & $\begin{array}{l}2 \\
4 \\
6 \\
8\end{array}$ & $\bar{t}$ & - & $+t$ \\
\hline chloroform & $\begin{array}{c}4900 \\
(1000)\end{array}$ & $\begin{array}{l}- \\
- \\
+\end{array}$ & $\begin{array}{l}2 \\
4 \\
6\end{array}$ & $\begin{array}{c}4000 \\
(1000)\end{array}$ & $\begin{array}{l}- \\
- \\
- \\
+\end{array}$ & $\begin{array}{r}2 \\
4 \\
6 \\
20 \\
\end{array}$ & + & - & $\overline{t+}$ \\
\hline acetylacetone & $\begin{array}{c}196 \\
(100)\end{array}$ & $\begin{array}{l}- \\
- \\
- \\
-\end{array}$ & $\begin{array}{r}2 \\
4 \\
6 \\
20 \\
\end{array}$ & $\begin{array}{c}410 \\
(100)\end{array}$ & $\begin{array}{r}- \\
- \\
+ \\
+\end{array}$ & $\begin{array}{r}2 \\
4 \\
6 \\
24 \\
\end{array}$ & - & - & + \\
\hline glyoxal & $\begin{array}{c}408 \\
(100)\end{array}$ & $\begin{array}{l}- \\
+ \\
+\end{array}$ & $\begin{array}{l}2 \\
4 \\
6\end{array}$ & $\begin{array}{c}350 \\
(100)\end{array}$ & $\begin{array}{l}++ \\
++ \\
++\end{array}$ & $\begin{array}{l}2 \\
4 \\
6\end{array}$ & + & ++ & ++ \\
\hline ionone & $\begin{array}{c}490 \\
(100)\end{array}$ & $+t$ & 2 & $\begin{array}{c}350 \\
(100)\end{array}$ & $\begin{array}{r}- \\
- \\
- \\
++\end{array}$ & $\begin{array}{r}2 \\
4 \\
6 \\
24 \\
\end{array}$ & - & $r$ & $r$ \\
\hline acrolein & $\begin{array}{c}408 \\
(100)\end{array}$ & + & 2 & $\begin{array}{l}35 \\
(10)\end{array}$ & $\begin{array}{l}- \\
- \\
- \\
+\end{array}$ & $\begin{array}{l}2 \\
4 \\
6 \\
8\end{array}$ & + & ++ & - \\
\hline trichloroetylen & he $\begin{array}{c}490 \\
(100)\end{array}$ & $\begin{array}{l}- \\
- \\
- \\
+\end{array}$ & $\begin{array}{r}2 \\
4 \\
6 \\
20 \\
\end{array}$ & & & & + & - & - \\
\hline tetrachloroetyl & $\begin{array}{r}\text { Lene } 490 \\
(100)\end{array}$ & $\begin{array}{l}- \\
- \\
- \\
+\end{array}$ & $\begin{array}{r}2 \\
4 \\
6 \\
20\end{array}$ & & & & + & + & + \\
\hline
\end{tabular}

S9-;Without microsomal activation s9+; With microsomal activation

k;bacterial cells were killed

$r$;reverse effect in Rec-assay

++ istrongly positive

+ ipositive

-inegative

Data of Ames test;RTECS 7)

Data of Rec-assay;Matsui et al. 10) 
Table 5 Positive chemicals and its concentration in $u m u$-test

\begin{tabular}{|lccc|}
\hline positive chemicals & s9mix & $\begin{array}{c}\text { Concentration } \\
\left(\mu \mathrm{g} \cdot \mathrm{ml}^{-1} \cdot \mathrm{OD}_{600}{ }^{-1}\right)\left(\mu \mathrm{g} \cdot \mathrm{ml}^{-1}\right)\end{array}$ \\
\hline m-dichlorobenzene & - & 442.5 & 100 \\
1,2,4-trichlorobenzene & - & 442.5 & 100 \\
bromoform & - & 476.2 & 100 \\
m-dichlorobenzene & + & 442.5 & 100 \\
dichloroacetic acid & + & 58.5 & 10 \\
trichloroacetic acid & + & 58.5 & 10 \\
chloral & + & 58.5 & 10 \\
formaldehyde & - & 123.5 & 10 \\
ionone & - & 492.6 & 100 \\
& & & \\
formaldehyde & + & 123.5 & 10 \\
furfural & + & 1234.6 & 100 \\
carvone & + & 1234.6 & 100 \\
glyoxal & + & 492.6 & 100 \\
acrolein & + & 49.3 & 10 \\
\hline
\end{tabular}

で1,2,4-トリクロロベンゼンは+S $9_{\text {mix }}$ で陽性と判定 されたが, $u m u$ テストでは20時間の反応時間をとって も陰性であった。ここで双方のテストで必ずしも同一 の投与濃度，培養条件でなく，しかも試験菌株が異な るゆえに,これらの結果をもってただちに assay の優 劣を論じられないことには注意を要する。

また Table 3 で示したオゾン処理生成物の反応中, 反応時間を長くとることでより陽性反応を強く示すよ うになったケースが示されていた。アセチルアセトン は+ $\mathrm{S} 9_{\text {mix }}$ で，反応 2 時間後では陰性反応しか示しえな かったが，反応 24 時間後には強い陽性反応を示すよう になった。グリオキサールはー $\mathrm{S} 9_{\mathrm{mix}}$ の場合, 反応 4 時 間後に陽性を呈しはじめた。イオノンは, Table 3 中で 濃度 $490 \mu \mathrm{g} \cdot \mathrm{m}^{-1} \cdot \mathrm{OD}_{600}{ }^{-1}\left(100 \mu \mathrm{g} \cdot \mathrm{m} l^{-1}\right)$ で細胞死が観 察されたが, $350 \mu \mathrm{g} \cdot \mathrm{m}^{-1} \cdot \mathrm{OD}_{600}{ }^{-1}\left(100 \mu \mathrm{g} \cdot \mathrm{m} l^{-1}\right)$ に減 じた結果, 反応開始24時間後にして, 強い陽性を示す ようになった。この場合は反応 2 時間で細胞死と判定 したものの, 結局静菌状態にあり, 増殖が抑制されて いたと考えられる。さらにアクロレインのー $\mathrm{S} 9_{\text {mix }}$ の場 合も，濃度を $408 \mu \mathrm{g} \cdot \mathrm{m}^{-1} \cdot \mathrm{OD}_{600}{ }^{-1}\left(100 \mu \mathrm{g} \cdot \mathrm{m} l^{-1}\right)$ と増 加させた場合に反応 2 時間で陽性反応を呈した。

以上の結果より，常法 2 時間の化学物質と菌懸濁液 に反応時間に対して，比較的長時間反応させてやるこ とにより，より強く陽性反応を示す物質があり，遺伝 毒性の判定を明確にすることができた。

このように，化学物質の種類，濃度によって陽性を 呈する時間に差異を生じることは, 各化学物質の細胞 の透過性, すなわち脂溶性や, DNA 鎖上へのアタック の速度, 損傷部位, さらには修復速度が化学物質ごと に異なっていることを示唆するものであると推察でき る。

\section{4. 結論}

水の塩素処理，あるいはオゾン処理により生成する とされている化学物質に関して，umuテストを実施 し，その遺伝毒性について検討した。得られた成果を 以下に要約する。

1) 塩素処理生成物とされる化学物質19種中, 菌体 と化学物質との反応時間 2 時間で陽性を示した物質を Table 5 に $9_{\mathrm{mix}}$ の有無と陽性を示した菌体当りの最 小投与濃度とともに示す。ここで示された最小投与濃 度は，あくまでも $10^{\mathrm{n}}$ 希釈列で得られた結果であり，よ り詳細な dose-response を得るためには，さらに細か い希釈列に関する検討が必要となる。ここでは $10^{\mathrm{n}}$ 希釈 列による結論ということに限定して要約して示すこと とする。

またラット肝酵素 $\left(\mathrm{S}_{\mathrm{mix}}\right)$ の投与により $u m u$ テスト に扔ける判定強度值 $(\mathrm{A}-\mathrm{B}) / \mathrm{B}$ を増した物質を以下 に示す。

クロロベンゼン, $p$-ジクロロベンゼン，ジクロロメ タン，1,2-ジクロロエタン，クロロ酢酸，ジクロロ 酢酸, トリクロロ酶酸, クロラール

$\mathrm{S} 9_{\mathrm{mix}}$ の投与で反応 2 時間内で増殖がみられず, 細胞死 と判定されたものは，1,2,4-トリクロロベンゼン，ブ ロモホルムであった。

2) オゾン処理生成物とされる化学物質 18 種中, 反 応時間 2 時間で陽性反応を呈したものを同様に Table 5 に示す。

$\mathrm{S} 9_{\mathrm{mix}}$ を投与して反応 2 時間内に増殖がみられな かった物質は，イオノンであった。

3 ) 試験菌株と化学物質との反応時間を $2 \sim 24$ 時間 と比較的長くとることで，陽性に転じた，あるいは陽 
性反応でもその遺伝毒性強度をさらに増した物質を検 索した。以下に示す。

$$
\begin{aligned}
& -\mathrm{S} 9_{\mathrm{mix}} ; \text { クロロホルム，トリクロロエチレン，テ } \\
& \text { トラクロロエチレン, グリオキサール, } \\
& \text { イオノン } \\
& +\mathrm{S} 9_{\mathrm{mix}} ; \quad \text { m-ジクロロベンゼン, ブロモホルム, ク } \\
& \text { ロロホルム，アセチルアセトン，イオノ } \\
& \text { ン，アクロレイン }
\end{aligned}
$$

以上の結果より化学物質の種類，濃度により陽性を呈 する時間に差を生じることは，物質の試験菌株におけ る細胞透過性, DNA の損傷。修復速度，損傷部位が化 学物質ごとに異なっていることを示唆するものである ことが推測された。

\section{謝 辞}

本研究を進めるにあたり，試験菌株の分与，試験法 に関して大阪府立公衆衛生研究所の小田美光博士に提 供していただいた。また試験法および RTECS 検索に あたっては同研究所中村清一博士のアドバイスをいた だいた。深甚の謝意を表する。

（原稿受付 1990 年 7 月 16 日）

（原稿受理 1991年6月30日）

\section{引用文 献}

1 ) Oda, Y., Nakamura, S., Oki, I. and Kato, T. (1985) Evaluation of the new system (umu-test) for the detection of environmental mutagens and carcinogens, Mutation
Research, 147, 219-229.

2 ）宗宮功, 山田春美（1987）オゾン処理特集 水中有機物との 反応, 工業用水, 344, 71-82。

3 ) 宗宮功, 遠藤伸一, 藤井滋穗（1980）塩素処理に関する基礎 的研究 (III) 一有機塩素化合物の生成について一, 下水道協会 誌, 17 (188), 1-12.

4) Registry of Toxic Effects of Chemical Substances, 1981 -82 EDITION and 1983-84 supplement, National Institute for Occupational Safety and Health.

5 ) Zeiger, E. (1987) Carcinogenicity of mutagens : predictive capability of Salmonella mutagenesis assay for rodent carcinogenicity, Cancer Research, 47, 1287-1296.

6 ) McCann, J., Choi, E., Yamasaki, E. and Ames B.N. (1975) Detection of carcinogens as mutagens in the Salmonella/ microsome test: assay of 300 chemicals, Proc. Natl. Acad. Sci. (USA), 72, 5135-5139.

7 ) Matsui, S., Yamamoto, R. and Yamada, H. (1989) The bacillus subtilis/microsome rec-assay for the detection of DNA damaging substances which may occur in chlorinated and ozonated waters, Water Science and Technology, 21, 875-887.

8 ) 柳田友道 (1981) 化学的ストレスに対する反応, 微生物科学 2 , 学会出版センター所収, pp.405-466。

9 ）茂岡忠義, 吉田喜久雄, 保坂千登勢, 早月陽子, 山内文雄 （1988）クロロフェノール類の活性污泥微生物に対する増殖阻 害性とその構造および微生物による分解性との関連, 衛生化 学, 34, 266-273.

10）小田美光 (1989) 活性酸素産生に係わる変異株に umu 遺伝子 導入した菌株を用いた高感度変異原検出系, 環境変異原研究, 11, 164 . 
ションタンクに比較して，バイオフィルターの酸素溶解性能が優れていることが明らかになった。坑火石発泡 体を充填した装置では, 微生物保持濃度を $4,000 \mathrm{~g} \cdot \mathrm{m}^{-3}$ 以下に維持できれば, 最大 $3 \mathrm{~kg}-\mathrm{O}_{2} \bullet \mathrm{kWh}^{-1}$ 程度の動力効 率を期待できる。

\section{化学酸化処理での反応生成物の遺伝毒性に関する研究}

小野 芳朗* 宗宮 功* 河村 正純*

* 京都大学工学部衛生工学科

〈水質污濁研究 Vol. 14 No.9（1991） pp.633 641〉

水道水や下水処理水の塩素あるいはオゾンによる化学酸化処理によって生成するとされる化学物質の遺伝毒 性を，DNA 修復にともなう修復エラーを誘発する遺伝子量を測定する umu-テストを用いて評価した。

化学物質と試験菌体の反応時間 2 時間では，m-ジクロロベンゼン，1,2,4-トリクロロベンゼン，ブロモホル ムジクロロ酢酸，トリクロロ酶酸，クロラール，ホルムアルデヒド，イオノン，フルフラール，カルボン，グ リオキサール，アクロレインに陽性が認められた。これらの濃度効果の結果は，他のバクテリアアッセイの結 果と比較された。

またクロロホルム，ブロモホルム，トリクロロエチレン，アセチルアセトン，アクロレイン等には菌体との 反応時間を長くとることで遺伝毒性を増す傾向が認められた。これらょり，化学物質の種類により，細胞膜透 過やDNA の損傷，修復に差のあることが示唆された。 